\title{
Pengaruh NaCl Fisiologis dan Ringer Laktat terhadap Kualitas Spermatozoa pada Suhu Ruang dan Fertilitas Telur Ayam Buras
}

\section{The Effect of Physiological Nacl and Ringer Lactate Diluent on Sperm Quality at Room Temperature and Egg Fertility of Native Chicken}

\author{
Iswati ${ }^{1 *}$, M. H. Natsir ${ }^{2}$, G. Ciptadi ${ }^{2}$, dan T. Susilawati ${ }^{2}$ \\ ${ }^{1}$ Jurusan Peternakan, Politeknik Pembangunan Pertanian Malang, Indonesia \\ ${ }^{2}$ Fakultas Peternakan, Universitas Brawijaya Malang, Indonesia \\ *Corresponding E-mail: iswati@polbangtanmalang.ac.id \\ (Diterima: 12 November 2020; Disetujui: 17 Januari 2021)
}

\begin{abstract}
ABSTRAK
Kualitas spermatozoa menentukan keberhasilan Inseminasi Buatan (IB). Pengencer sederhana yang memiliki sifat buffer dan isotonik dapat digunakan sebagai pengencer semen ayam. Tujuan penelitian ini adalah membandingkan kualitas spermatozoa ayam buras dalam pengencer Natrium chlorida $(\mathrm{NaCl})$ Fisiologis dan Ringer Laktat (RL) pada penyimpanan suhu ruang dan menguji fertilitas telur berdasarkan lama simpan terbaik. Penelitian ini menggunakan semen yang berasal dari 2 pejantan ayam buras, penyimpanan semen selama 2 jam pada suhu ruang dengan interval pengamatan 30 menit. Inseminasi dilakukan pada 20 ekor betina ayam buras. Parameter yang diamati adalah motilitas, viabilitas dan abnormalitas spermatozoa. Analisis statistik kualitas semen dengan Analysis of Variant (ANOVA) pola tersarang dan analisis fertilitas telur dengan uji chi-square. Hasil penelitian menunjukkan bahwa penambahan pengencer $\mathrm{NaCl}$ Fisiologis dan $R L$ berpengaruh nyata $(\mathrm{P}<0,05)$ terhadap penurunan kualitas semen selama penyimpanan suhu ruang. Lama simpan terbaik pada suhu ruang yang masih mampu mempertahankan kualitas semen adalah pada menit ke-30 dan hasil ini digunakan untuk aplikasi IB dengan fertilitas telur berbeda nyata $(\mathrm{P}<0,05)$ masingmasing perlakuan yaitu $82,61 \%$ ( $\mathrm{NaCl}$ Fisiologis) dan $60,01 \%(\mathrm{RL})$. Kesimpulan dari penelitian ini bahwa kualitas spermatozoa ayam sampai menit ke-30 pada suhu ruang masih memenuhi syarat untuk aplikasi IB, dan fertilitas telur terbaik pada penggunaan pengencer $\mathrm{NaCl}$ Fisiologis.
\end{abstract}

Kata kunci: fertilitas, Natrium chlorida, Ringer Laktat, spermatozoa ayam

\section{ABSTRACT}

The sperm quality determines the success of Artificial Insemination (AI). The simple diluent, which had a buffer and isotonic characteristic, can be used as a chicken semen diluent. The purpose of this study was to compare the sperm quality of native chicken in Physiological Natrium chloride (NaCl) and Ringer's lactate (RL) diluent at room temperature storage and to test the egg fertility based on the best storage time. This study used semen from 2 native chickens, storing semen for 2 hours at room temperature with an observation interval of 30 minutes. Insemination was carried out on 20 native chickens. The parameters observed were motility, viability, and abnormality of sperm. Statistical analysis of sperm quality using Analysis of Variant (ANOVA) nested patterns and analysis of egg fertility using the chi-square test. The results showed that the addition of $0.9 \% \mathrm{NaCl}$ and $\mathrm{RL}$ diluent had a significant effect $(P<0.05)$ on the decrease in semen quality during storage at room temperature. The best storage time at room temperature, which was still able to maintain the quality of the was at 30 minutes, and these results were used for AI applications with significantly different on egg fertility $(P<0.05)$ respectively $82.61 \%(0.9 \% \mathrm{NaCl})$ and $60.01 \%(R L)$. The conclusion of this study that the quality of spermatozoa with $0.9 \% \mathrm{NaCl}$ and RL diluent decreased during storage at room temperature, the sperm quality until the 30th minute still fulfilled the requirements for AI application, and the best egg fertility was shown in the use of $0.9 \% \mathrm{NaCl}$ diluent.

Keywords: fertility, Natrium chloride, Ringer's Lactate, chicken sperm 


\section{PENDAHULUAN}

Kemajuan bidang breeding unggas dapat didukung dengan pemanfaatan bioteknologi, untuk meningatkan produktivitas ternak. Salah satu Bioteknologi dalam bidang reproduksi unggas adalah Inseminasi Buatan (IB) (Nahak et al., 2017). Inseminasi buatan sebagai metode perkawinan dengan efisiensi pemanfaatan pejantan unggul secara genetik (Mohan et al., 2018). Keberhasilan aplikasi IB sangat dipengaruhi oleh kualitas semen dan bahan pengencer yang digunakan untuk penyimpanan (Ax et al., 2000).

Semen ayam setelah penampungan harus segera mungkin digunakan untuk insemiansi buatan (IB). Jika tidak segera digunakan untuk IB maka semen ayam dilakukan penyimpanan. Kualitas semen ayam selama penyimpanan ditentukan oleh jenis pengencer, metode penyimpanan dan lama penyimpanan. Metode penyimpanan dapat dilakukan pada suhu ruang, suhu dingin dan suhu beku. Namun sejauh ini semen ayam masih digunakan dalam keadaan segar (fresh semen) tanpa penyimpanan untuk aplikasi IB karena kualitas spermatozoa menurun tajam selama pendinginan dan pembekuan antara lain penurunan jumlah spermatozoa hidup, morfologis normal dan peningkatan spermatozoa mati dan spermatozoa dengan leher bengkok (Siudzin'ska and Łukaszewicz, 2008; Wishart, 2009).

Spermatozoa membutuhkan kecukupan nutrien untuk mempertahankan hidupnya selama penyimpanan yang berasal dari bahan pengencer yang ditambahkan. Bahan pengencer yang digunakan harus memenuhi syarat memiliki daya penyanggah (buffer), bersifat isotonis, mampu menyediakan lingkungan optimal untuk mempertahankan hidup spermatozoa, serta bertujuan memperbanyak volume semen, dan untuk meningkatkan jumlah dosis inseminasi dari setiap koleksi (Susilawati, 2011; Danang et al., 2012; Vasicek et al., 2015)

Pengembangan pengencer berawal dari penggunaan larutan sederhana $\mathrm{NaCl}$ diikuti oleh pengencer kompleks yang mengandung regulator osmotik, substrat energi dan buffer (Mohan et al., 2018). Bahan pengencer semen unggas komersial yang lebih kompleks telah banyak digunakan antara lain pengencer Lake's, Beltsville Poultry Semen Extender (BPSE), Instruments for Veterinary Medicine (IMV) (Hudson et al., 2016), IGGKP (Lukaszewicz, 2001), EK (Lukaszewicz, 2002), CARI (Mohan, et al., 2017) dengan komposisi yang berbeda dengan tekanan osmotik dan $\mathrm{pH}$ yang sesuai untuk semen yang umumnya digunakan untuk penyimpanan dingin dan pembekuan semen unggas (Tangpakdeewijit, 2015). Beberapa pengencer komersial yang kompleks tersebut harus import dan harganya relatif mahal, sehingga perlu penggunaan pengencer sederhana yang terjangkau oleh kalangan peternak.

Natrium chlorida $(\mathrm{NaCl}) \quad 0,9 \%$ yang terdiri dari garam natrium dan chlorida dapat digunakan sebagai pengencer semen ayam. Penelitian sebelumnya menyatakan bahwa kualitas semen ayam hanya mampu bertahan selama kurang lebih 30-45 menit pada suhu ruang dengan pengencer $\mathrm{NaCl}$ Fisiologis (Lubis, 2011). Selain itu bahan lain yang dapat digunakan adalah Ringer Lactat (RL) yang memiliki komposisi lebih lengkap, bersifat penyanggah dan isotonik yang dapat mendukung daya hidup spermatozoa dalam waktu yang lebih lama (Danang et al., 2012). Kedua bahan tersebut, baik $\mathrm{NaCl} 0,9 \%$ maupun Ringer laktat merupakan bahan pengencer yang sederhana, mudah didapat, harga relatif murah namun ada perbedaan kandungan ion dan mineral didalamnya. Ringer laktat belum banyak digunakan untuk pengencer semen pada aplikasi IB ayam. Sehinga penelitian ini bertujuan untuk membandingkan kualitas spermatozoa ayam buras dalam pengencer $\mathrm{NaCl}$ Fisiologis dan Ringer Laktat pada suhu ruang selama 2 jam penyimpanan, sehingga dapat diketahui pada menit ke berapa kualitas spermatozoa masih layak digunakan untuk IB serta menguji fertilitas telur dari kedua bahan pengencer pada lama simpan terbaik.

Pengaruh $\mathrm{NaCl}$ Fisiologis dan ... (Iswati et al.) 


\section{METODE}

\section{Hewan Percobaan}

Penelitian ini menggunakan ayam buras jantan berjumlah 2 ekor, umur 2 tahun. Tahap 1 adalah membandingkan kualitas semen pada 2 pengencer yang berbeda yaitu: $\mathrm{NaCl}$ Fisiologis dan Ringer laktat (RL). Tahap ke-2 adalah penerapan IB pada 20 ekor ayam buras betina, untuk uji fertilitas dari dua pengencer tersebut pada durasi waktu yang menunjukkan kualitas terbaik

\section{Penampungan Semen}

Pengumpulan semen ayam menggunakan metode artificial kloaka dan satu ekor ayam betina sebagai betina pemancing (Chelmonska et al., 2008; Iswati et al., 2018). Penampungan semen dilakukan pada pagi hari dengan frekuensi dua kali seminggu (Gethachew, 2016). Semen yang terkumpul dibagi menjadi dua perlakuan pengencer ( $\mathrm{NaCl}$ Fisiologis dan $\mathrm{RL}$ ) dengan delapan ulangan/penampungan.

\section{Pengencer}

Pengencer yang digunakan dalam penelitian ini adalah $\mathrm{NaCl}$ Fisiologis atau Normal saline dengan komposisi: Natrium chlorida 4,5 g dalam $500 \mathrm{ml}$ water injection dengan osmolaritas $308 \mathrm{mOsm} / 1$. Pengencer ringer laktat dengan komposisi: kalsium klorida $2 \mathrm{H}_{2} 0 \quad 0,1$ g, Kalium Klorida 0,15 $\mathrm{g}$, natrium klorida $3,00 \mathrm{~g}$, natrium laktat $1,55 \mathrm{~g}$ dalam $500 \mathrm{ml}$ water injection dengan osmolaritas $273 \mathrm{mOsm} / 1$.

\section{Evaluasi semen}

Semen segar setelah penampungan dilakukan evaluasi makroskopik yang meliputi: volume, $\mathrm{pH}$, warna, konsistensi dan evaluasi mikroskopik meliputi konsentrasi, gerak massa, motilitas individu, viabilitas dan abnormalitas spermatozoa. Metode pengukuran variabel dalam penelitian ini menurut Ax et al., (2008); Susilawati, (2011); Ismaya, (2014). Semen segar yang memenuhi syarat motilitas minimum $70 \%$ dilanjutkan dengan pengenceran pada 2 bahan pengencer $\mathrm{NaCl}$ Fisiologis dan Ringer Laktat (RL) dengan perbandingan (1:4) (Siudzin'ska dan Łukaszewicz, 2008; Habibullah, 2015) dan disimpan pada suhu ruang. Evaluasi semen dilakukan pada menit ke-1, 30, 60, 90, dan 120 (2 jam) yang meliputi motilitas individu, viabilitas dan abnormalitas spermatozoa.

\section{Insemiansi Buatan}

Tahap penelitian selanjutnya adalah inseminasi terhadap 20 ekor ayam betina yang dibagi menjadi 2 perlakuan (masing-masing 10 ekor). Perlakuan 1 adalah inseminasi dengan semen segar yang telah ditambahkan $\mathrm{NaCl}$ Fisiologis dan perlakuan 2 penambahan pengencer RL. Semen dalam bahan pengencer dibiarkan selama 30 menit pada suhu ruang (sesuai hasil terbaik pada tahap sebelumnya), kemudian digunakan untuk IB. Insemiansi dilakukan dengan deposisi semen intravaginal dan waktu IB pada sore hari (Tabatabaei, 2010). Telur dikoleksi selama 3 hari mulai hari kedua setelah IB.

\section{Penetasan}

Telur yang terkumpul kemudian dilakukan tahap penetasan pada suhu $37,5^{\circ}-38^{\circ} \mathrm{C}$ dan kelembaban $60-65 \%$ (Boleli et al., 2016; Addo et al., 2018). Candling dilakukan pada penetasan hari ke-7 untuk mengetahui fertilitas telur Fertilitas telur sesuai acuan Modupe et al. (2013); Mohan et al. (2015), Fikremariam dan Tilahun, (2016) bahwa persentase fertilitas sebagai rasio jumlah telur fertil terhadap jumlah total telur yang masukkan pada mesin tetas.

\section{Analisis Data dan Statistik}

Analysis of variants (ANOVA) pola tersaranag (nested) dilakukan untuk menguji pengaruh pengencer $\mathrm{NaCl}$ Fisiologis dan RL dan lama penyimpanan terhadap kualitas semen, dimana lama penyimpanan tersarang pada jenis pengencer. Karena hanya terdapat dua jenis perlakuan ( $\mathrm{NaCl}$ Fisiologis dan $\mathrm{RL}$ ) pengujian lanjutan tidak dilakukan, sedangkan untuk mengetahui ada tidaknya perbedaan antara lama waktu pengamatan dilakukan Confidence Interval pada taraf 0,05. Data penelitian dianalisis menggunakan program SPSS 16. Persentase fertilitas telur dianalisis 
Tabel 1. Hasil evaluasi semen segar ayam buras sebelum perlakuan pengenceran.

\begin{tabular}{|c|c|c|}
\hline Variabel & Hasil Pengamatan (Rata-rata \pm SE) & Standar \\
\hline \multicolumn{3}{|l|}{ Makroskopis: } \\
\hline Volume (ml) & $0,4 \pm 0,04$ & $0,2-0,5$ \\
\hline Warna & Putih susu & Putih susu \\
\hline $\mathrm{Bau}$ & khas & khas \\
\hline Konsistensi & kental & kental \\
\hline $\mathrm{pH}$ & $7,87 \pm 0,12$ & $7,2-7,6$ \\
\hline \multicolumn{3}{|l|}{ Mikroskopis: } \\
\hline Konsentrasi $\left(10^{9} / \mathrm{ml}\right)$ & $3.849 \pm 289$ & $3.000-7.000$ \\
\hline Motilitas (\%) & $85 \pm 0.94$ & $>70 \%$ \\
\hline Spermatozoa hidup (\%) & $93,5 \pm 0,71$ & $60-80$ \\
\hline Abnormalitas (\%) & $11,9 \pm 0,63$ & $10-15$ \\
\hline
\end{tabular}

dengan analisis non-parametrik chi-square (Madeddu, et al., 2013; Iswati, et al., 2017).

\section{HASIL DAN PEMBAHASAN}

\section{Karakteristik Semen Segar}

Setelah penampungan, semen diperiksa secara makroskopik dan mikroskopik untuk menentukan apakah memenuhi syarat untuk diencerkan. Data kualitas semen segar kemudian dilakukan analisis deskriptif dan dibandingkan dengan standar menurut Garner dan Hafez (2008) dan Susilawati (2011). Hasil pemeriksaan menunjukkan bahwa kualitas semen dalam keadaan normal dan dapat dilanjutkan proses pengenceran. Hasil evaluasi semen segar setelah penampungan menunjukkan bahwa semen layak untuk diencerkan (Tabel 1).

Kualitas semen hasil penampungan meliputi makroskopik dan mikroskopik. Volume semen rata-rata $(0,4 \pm 0,04 \mathrm{ml})$ yang diperoleh pada penelitian ini termasuk kategori normal sesuai standar dan menurut Suprijatna et al. (2005) bahwa volume semen ayam $0,3-1,0 \mathrm{ml}$ setiap penampungan. Warna semen ayam pada umunya adalah putih susu, tanpa tercampur kotoran, feses dan darah (Peters et al., 2008). Bau yang ditimbulkan dari semen ayam adalah khas semen ayam, tidak terdeteksi bau abnormal pada semen.

Derajat keasaman $(\mathrm{pH})$ semen $(7,87 \pm$ $0,12)$ sedikit lebih tinggi diatas standar namun hasil itu masih tergolong normal menurut Peters et al. (2008) yang menyatakan bahwa semen ayam sedikit alkalis dengan $\mathrm{pH}$ berkisar antara 6,0- 8,0 (Donoghue dan Wishart, 2000). Pada penelitian ini, semen yang di hasilkan memiliki konsistensi kental sesuai penelitian sebelumnya (Mohan et al., 2018; Ax et al., 2008; Susilawati, 2011) yang menyatakan bahwa konsistensi semen memiliki korelasi dengan konsentrasi spermatozoa, semakin kental konsistensinya berarti semakin banyak jumlah spermatozoa dalam semen.

Konsentrasi spermatozoa merupakan jumlah spermatozoa per ml ejakulat semen. Ayam memiliki konsentrasi spermatozoa yang lebih tinggi dari ternak lainnya karena volume seminal plasma yang terdapat pada semen ayam lebih rendah (Garner dan Hafez, 2008; Mohan et al., 2018). Pada penelitian ini konsentrasi spermatozoa tergolong baik yaitu rata-rata $3.849 \pm 289\left(10^{6} / \mathrm{ml}\right)$. Hasil ini sesuai dengan pendapat Garner dan Hafez (2008) bahwa konsentrasi normal spermatozoa ayam berkisar 3000-7000 juta/ml. Penilaian motilitas massa adalah sangat baik yaitu nampak pergerakan massa spermatozoa membentuk gelombang tebal menyerupai awan. Rataan motilitas individu semen segar 
Tabel 2. Kualitas spermatozoa (motilitas, viabilitas, abnormalitas) dengan pengencer $\mathrm{NaCl}$ Fisiologis dan Ringer Laktat selama dua jam penyimpanan pada suhu ruang.

\begin{tabular}{|c|c|c|c|c|c|c|}
\hline \multirow{3}{*}{$\begin{array}{l}\text { Pengamatan } \\
\text { menit ke- }\end{array}$} & \multicolumn{2}{|c|}{$\begin{array}{l}\text { Motilitas (\%) } \\
\text { Rata-rata } \pm \text { SE }\end{array}$} & \multicolumn{2}{|c|}{$\begin{array}{l}\text { Viabilitas }(\%) \\
\text { Rata-rata } \pm \text { SE }\end{array}$} & \multicolumn{2}{|c|}{$\begin{array}{c}\text { Abnormalitas (\%) } \\
\text { Rata-rata } \pm \text { SE }\end{array}$} \\
\hline & $\mathrm{NaCl}$ & & $\mathrm{NaCl}$ & & $\mathrm{NaCl}$ & \\
\hline & Fisiologis & $\mathrm{RL}$ & Fisiologis & RL & Fisiologis & RL \\
\hline 1 & $81,3 \pm 1,57$ & $83,8 \pm 0,82$ & $85,6 \pm 3,59$ & $86,9 \pm 2,02$ & $11,8 \pm 0,90$ & $11,8 \pm 0,83$ \\
\hline 30 & $74,4 \pm 1,13$ & $78,8 \pm 1,57$ & $80,9 \pm 4,73$ & $78,6 \pm 3,37$ & $15,3 \pm 1,20$ & $15,2 \pm 0,8$ \\
\hline 60 & $60.0 \pm 3,13$ & $72,5 \pm 2,31$ & $72,0 \pm 3,31$ & $78,6 \pm 2,64$ & $20,4 \pm 1,96$ & $17.0 \pm 1,99$ \\
\hline 90 & $56,9 \pm 2,82$ & $68,8 \pm 2,06$ & $67,9 \pm 1,75$ & $76,0 \pm 2,08$ & $21,2 \pm 1,63$ & $18,9 \pm 1,85$ \\
\hline 120 & $51,3 \pm 3,37$ & $61,9 \pm 2,09$ & $66,5 \pm 2,63$ & $73,2 \pm 1,55$ & $24,2 \pm 1,45$ & $18,1 \pm 2,19$ \\
\hline Pvalue & \multicolumn{2}{|c|}{$0.00^{*}$} & \multicolumn{2}{|c|}{$0.00 *$} & \multicolumn{2}{|c|}{$0.00^{*}$} \\
\hline $\begin{array}{l}\text { Convidence } \\
\text { interval (CI) }\end{array}$ & \multicolumn{2}{|c|}{ tidak berpotongan* } & \multicolumn{2}{|c|}{ tidak berpotongan * } & \multicolumn{2}{|c|}{ tidak berpotongan * } \\
\hline
\end{tabular}

Keterangan: * = berbeda nyata $(\mathrm{P}<0,05)$

pada penelitian ini adalah $85,0 \pm 0,94(\%)$, hasil ini memenuhi kriteria semen segar yang dapat diproses untuk pengenceran.

Semen segar pada penelitian ini memiliki persentase Viabilitas spermatozoa

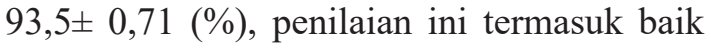
sebagaimana yang disampaikan oleh Lukman et al. (2014) bahwa viabilitas spermatozoa yang baik antara $60-75 \%$. Hasil penelitian ini lebih tinggi dari yang dilaporkan Tarif et al. (2013) pada ayam Sasso Line yang mencapai viabilitas tertinggi $89 \pm 1,5 \%$. Hasil Evaluasi abnormalitas semen segar dalam penelitian

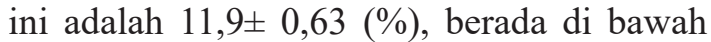
$15 \%$ sehingga termasuk kategori baik. Parameter morfologi abnormal ini penting karena jika persentase abnormalitas baik primer dan sekunder lebih dari 20\% memiliki daya konsepsi yang rendah (Susilawati, 2011; Ismaya, 2014). Morfologi abnormal semen ayam yang baik adalah berkisar 1015\% (Garner dan Hafez, 2008). Abnormaliats yang banyak ditemui pada penelitian ini adalah pada bagian ekor antara lain ekor putus, ekor menggulung, ekor melingkar dan ekor menekuk yang merupakan abnormalitas sekunder.

\section{Kualitas Spermatozoa dengan penambahan pengencer $\mathrm{NaCl}$ Fisiologis dan Ringer Laktat pada suhu ruang}

Kualitas spermatozoa pada pengencer $\mathrm{NaCl}$ Fisiologis berbeda nyata $(\mathrm{P}<0,05)$ dibandingkan penambahan pengencer Ringer Laktat (Tabel 2). Motilitas spermatozoa dan viabilitas mengalami penurunan yang nyata $(\mathrm{P}<0,05)$ sedangkan abnormalitas meningkat secara nyata selama waktu penyimpanan dari menit ke 1 sampai menit ke 120 pada suhu ruang (berdasarkan convidence interval antara lower bound dan upper bound yang tidak berpotongan pada setiap waktu pengamatan).

\section{Motilitas spermatozoa}

Evaluasi motilitas spermatozoa dilakukan secara mikroskopik sebagai parameter utama kualitas spermatozoa yang menunjukkan kemampuan spermatozoa menuju tempat fertilisasi (Bakst and Dyamond, 2013). Kualitas spermatozoa yang bagus ditunjukkan dengan tingginya motilitas progresif. Motilitas progresif adalah kemampuan spermatozoa bergerak maju yang menentukan kecepatannya sampai pada tempat fertilisasi. Motilitas spermatozoa merupakan salah satu ukuran penting yang menunjukkan kemampuan spermatozoa membuahi ovum dalam proses fertilisasi (Danang et al., 2012; 
Zahariev et al., 2007). Persentase spermatozoa motil merupakan variabel paling utama dalam penentuan kualitas spermatozoa (Rizal dan Herdis, 2008; Getachew, 2016).

Motilitas spermatozoa lebih baik pada pengencer RL daripada pengencer $\mathrm{NaCl}$ Fisiologis (Tabel 2). Ringer Laktat mengandung lebih banyak cairan elektrolit dibandingkan $\mathrm{NaCl}$ Fisiologis, yang berfungsi mempertahankan motilitas lebih baik. Hal ini sebagaimana dikemukakan oleh Nurcholidah et al. (2006) bahwa larutan Ringer Laktat mengandung unsur elektrolit yang sama dengan plasma semen seperti Natrium, chlorida, kalsium dan magnesium. Ringer Laktat mengandung Na-laktat yang diperlukan untuk memenuhi kebutuhan ion bikarbonat untuk mempertahankan keasaman larutan serta mempertahankan tekanan osmotik larutan (Ridwan dan Rusdin, 2008). Motilitas spermatozoa menit pertama pada peneilitian ini lebih tinggi daripada penelitian Iswati et al. (2018) yang menggunakan Ringer Laktat pada penyimpanan suhu dingin pada jam ke 0 dimana motilitas hanya mencapai $71 \pm 2,77 \%$.

\section{Viabilitas spermatozoa}

Faktor kualitas semen yang lain sebagai penentu keberhasilan inseminasi buatan antara lain viabilitas spermatozoa. Viabilitas merupakan variable penting karena hanya spermatozoa yang bertahan hidup dalam saluran reproduksi betina yang mampu mencapai tempat fertilisasi dan membuahi ovum. Hasil penelitian ini menunjukkan bahwa kualitas semen yang diberi pengencer $\mathrm{NaCl}$ Fisiologis dan Ringer Laktat selama dua jam pengamatan menunjukkan viabilitas yang berbeda nyata $(\mathrm{P}<0,05)$.

Viabilitas spermatozoa menurun seiring dengan bertambahnya waktu pengamatan dan sampai dengan akhir pengamatan 120 menit viabilitas spermatozoa pada suhu ruang diatas $60 \%$, hal ini masih memenuhi syarat untuk inseminasi buatan sebagaimana yang diungkapkan oleh Lukman et al. (2014) bahwa syarat viabilitas yang baik diatas $60 \%$. Kualiats semen pada pengencer RL cenderung lebih baik daripada $\mathrm{NaCl}$, karena kandungan RL yang lebih lengkap yaitu adanya senyawa Na-laktat menyebabkan spermatozoa bertahan hidup lebih lama dengan kualitas viabilitas yang lebih baik (Ridwan dan Rusdin, 2008). Salah satu sumber energi pada RL adalah laktat yang merupakan hasil glukoneogenesis dari metabolisme karbohidrat, pemecahan gula terjadi di sitoplasma sel menghasilkan energi berupa ATP. Adenosine TriPhosphate tersebut sebagai sumber energi bagi spermatozoa selama penyimpanan untuk mempertahankan hidupnya (Yamte et al., 2013).

\section{Abnormalitas spermatozoa}

Rataan abnormalitas spermatozoa semakin meningkat dengan bertambahnya waktu pengamatan. Abnormalitas yang masih memenuhi syarat kualiats yang baik adalah pada pengenceran $\mathrm{NaCl}$ Fisiologis dan $\mathrm{RL}$ sampai menit ke 30. Sedangkan pada menit ke 60 sampai 120 tidak memenuhi syarat karena abormalitas diatas $15 \%$.

Spermatozoa yang normal yang mampu menembus ovum untuk pembuahan. Morfologi spermatozoa yang abnormal sangat berhubungan dengan daya fertilitas ternak, abnormalitas spermatozoa lebih dari $20 \%$ dapat menurunkan kemampuan fertilisasi spermatozoa (Susilawati, 2011). Menurut Garner dan Hafez (2008) pada bangsa unggas morfologi normal spermatozoa harus memenuhi persentase minimal $85-90 \%$, yang artinya spermatozoa abnormal tidak boleh lebih dari 15\% agar dapat digunakan untuk inseminasi. Abnormalitas yang terlihat dari pememeriksaan antara lain: ekor menggulung, ekor menekuk, ekor putus dan bagian mid piece menekuk.

Hasil penelitian ini secara umum menunjukkan bahwa penambahan pengencer $\mathrm{NaCl}$ Fisiologis dan RL pada semen ayam yang disimpan pada suhu ruang, menunjukkan penurunan kualiats (motilitas, viabiliats dan abnormalitas) seiring dengan bertambahnya waktu pengamatan. Hasil evaluasi kualitas semen sampai pada menit ke-30 pada $\mathrm{NaCl}$ Fisiologis maupun RL masih memenuhi syarat 
Tabel 3. Fertilitas telur (\%) hasil Insemiansi Buatan dengan pengencer $\mathrm{NaCl}$ Fisiologis dan Ringer Laktat

\begin{tabular}{lc}
\hline Perlakuan & Rataan fertilitas (\%) \\
\hline IB dengan pengencer NaCl Fisiologis & 82,61 \\
IB dengan pengencer Ringer Laktat (RL) & 60,01 \\
\hline
\end{tabular}

untuk apliaksi IB, namun setelah menit ke 30 abnormalitas spermatozoa sudah melebihi batas normal yaitu diatas $15 \%$, diasumsikan akan menurunkan kemampuan spermatozoa untuk membuahi ovum, maka penggunaan kedua pengencer untuk apliaksi IB tidak lebih dari 30 menit.

\section{Fertiliatas telur hasil IB dengan pengencer $\mathrm{NaCl}$ Fisiologis dan Ringer Laktat setelah 30 menit penyimpanan suhu ruang}

Ukuran keberhasilan program IB adalah fertilitas telur dari ayam betina (Bakst and Dyamond, 2013). Fertilitas tergantung pada kualitas dan kuantitas spermatozoa yang dideposisikan (Brillard, 2003). Penentuan fertilitas telur melalui candling pada hari ke-7 inkubasi. Fertilitas telur dihitung dari total telur yang fertil di bagi dengan total telur yang diinkubasi dikalikan 100\% (Modupe et al., 2013; Fikremariam and Tilahun, 2016).

Perbedaan yang nyata hasil fertilitas telur dengan pengencer $\mathrm{NaCl}(82,61 \%)$ dan RL (60,01\%), dimana hasil terbaik dengan menggunakan pengencer $\mathrm{NaCl}$ Fisiologis (Tabel 3). Hasil analisis antara pengenceran dengan persentase fertilitas dilakukan dengan uji chi square, didapatkan nilai $\mathrm{X}^{2}$ hitung sebesar 7,42> $X^{2}$ tabel sebesar 3,84, sehingga terdapat pengaruh yang nyata jenis pengencer semen terhadap fertilitas telur.Persentase Fertilitas telur dengan pengencer $\mathrm{NaCl}$ Fisiologis ini hampir sama dengan hasil Mohan et al. (2015) yang menyebutkan fertilitas telur pada Guenia fowl menggunakan larutan $\mathrm{NaCl}$ Fisiologis pada semen segar adalah $82,4 \%$. Fertilitas telur dengan pengencer RL pada penelitian ini lebih rendah daripada penelitian Iswati et al. (2017) dimana hasil IB dengan pengencer RL menghasilkan fertilitas $76 \%$. Hasil penelitian ini juga lebih rendah dari laporan Ridwan dan Rusdin (2008) bahwa IB dengan pengencer RL menghasilkan fertilitas $74,73 \%$.

Fertilitas telur yang diharapkan dari hasil Inseminasi Buatan adalah 85\% sedangkan menurut Tabatabaei (2010) Persentase fertilitas yang diharapkan dari IB pada ayam adalah $89 \%$. Hal yang sama diungkapkan oleh Mohan et al. (2016) bahwa persentase fertilitas hasil insemiansi buatan pada unggas umumnya berkisar 73-87\%. Vasicek et al. (2015) juga menyatakan bahwa fertilitas hasil IB adalah 82,99\% menggunakan pengencer $\mathrm{NaCl}$ Fisiologis pada semen yang disimpan 0,5 jam pertama pada suhu $4^{\circ} \mathrm{C}$, sehingga larutan $\mathrm{NaCl}$ Fisiologis bisa sebagai pengencer semen ayam yang lebih murah dan lebih mudah didapatkan untuk penggunaan praktis dilapangan.

Inseminasi Buatan dapat dilakukan satu atau dua kali seminggu untuk memastikan adanya populasi spermatoza pada Utero Vaginal Juntion (UVJ). Bagian UVJ terdapat Sperm Storage Tubule (SST) yang merupakan invaginasi permukaan epitel sebagai tempat penyimpanan utama spermatozoa atau sperm nest sebelum menuju tempat fertilisasi. Pada bagian SST tersebut sperma ayam mampu bertahan hingga 2 minggu (Bakst and Dyamond, 2013) dan keluar dari sperm nest sedikit demi sedikit antara waktu ovulasi dan oviposisi menuju infundibulum untuk fertilisasi.

Hasil penelitian ini menunjukkan bahwa fertilitas telur menggunakan pengencer RL lebih rendah daripada menggunakan pengencer $\mathrm{NaCl}$, kemungkinan karena adanya kandungan asam laktat dari larutan RL yang mempengaruhi metabolisme spermatozoa, sebagaimana dikemukakan oleh Ridwan dan Rusdin (2008) bahwa unsur-unsur kimia dan substrat nutrisi pengencer semen akan 
berpengaruh terhadap proses metabolisme spermatozoa pada semen yang disimpan cukup lama sebelum diinseminasikan. Kualitas semen in vitro cenderung lebih baik pada pengencer RL namun belum mampu menjamin tingkat fertilitas yang tinggi secara in vivo, kemungkinannya terjadi penurunan daya hidup spermatozoa pada pengencer RL sebelum inseminasi dan memasuki UVJ meskipun waktu selesainya IB diperkirakan kurang dari 30 menit. Hafez (2008), bahkan mengemukakan bahwa spermatozoa dapat kehilangan fertilitasnya sekalipun secara visual masih hidup sehingga keberhasilan fertilisasi dapat menurun.

\section{KESIMPULAN}

Kesimpulan dari penelitian ini adalah:

1. Kualitas spermatozoa pada pengencer $\mathrm{NaCl}$ Fisiologis dan RL selama penyimpanan suhu ruang mengalami penurunan dan kualitas spermatozoa pada pengencer $\mathrm{NaCl}$ Fisiologis lebih baik daripada RL.

2. Lama simpan terbaik dari kedua pengencer tersebut adalah sampai menit ke-30 dan menghasilkan fertilitas terbaik hasil IB pada penggunaan pengencer $\mathrm{NaCl}$ Fisiologis.

3. Pengencer $\mathrm{NaCl}$ Fisiologis dapat digunakan sebagai pengencer alternatif yang lebih murah dan mudah di dapat untuk aplikasi IB ayam.

\section{UCAPAN TERIMA KASIH}

Ucapan terimaksih kepada Direktur
Politeknik Pembangunan Pertanian
(POLBANGTAN) Malang yang telah
memberikanijin penelitian, khsususnyabagian
Instalasi Ternak Unggas dan Laboratorium
Reproduksi dengan segala fasilitas sarana dan
prasarana penelitian.

\section{DAFTAR PUSTAKA}

Addo, A. J. A. Hamidu., A. Y. Ansah, and K. Adomako. 2018. Impact of Egg Storage Duration and Temperature on Egg Quality, Fertility, Hatchability and Chick Quality in Naked Neck Chickens. International Journal of Poultry Science.17: 175-183.

Ax, R. L., M. R. Dally., B. A. Didion., R. W. Lenz., C. C. Love., D. D. Varner., B. Hafez, and M. E. Bellin. 2008. Semen Evaluation in Farm Animal Reproduction ed by Hafez ESE. 7 th edition. Lea and Febiger: 365-375.

Bakst, M. R. and J. S. Dyamond. 2013. Artificial Insemination in Poultry in Succes in Artificial Insemination. Edited by Alemayehu Lemma. INTECH: 176-195.

Boleli, I. C., V. S. Morita., Jr. J. B Matos., M. Thimotheo, and V. R. Almeida. 2016. Poultry Egg Incubation: Integrating and Optimizing Production Efficiency. Brazilian Journal of Poultry Science.2: 1-16.

Brillard, J. P. 2003. Practical aspects of fertility in poultry. World Poult. Sci. J. 59: 441-446.

Chelmonska, B., A. Jerysz., E. L. Ukaszewicz., A. Kowalczyk, and I. Malecki. 2008. Semen Collection from Japanese Quail (Coturnix japonica) Using a Teaser Female.Turk.J. Vet. Anim. Sci.32(1): 19-24.

Danang, D. R., N. Isnaini, and P. Trisunuwati. 2012. Save Old influence on the Quality of Sperm Semen Native Chicken In Ringer's diluent at $4{ }^{\circ} \mathrm{C}$. Jurnal Ternak Tropika . 13(1): 47-57.

Donoghue. A. M. and G. J. Wishart. 2000. Storage of poultry semen. Animal Reproductive Science.62: 213-232.

Fikremariam, F. and A. Tilahun. 2016. Fertility and Hatchability of Fayoumi and Dominant Breeds of Chicken in 
Debere Zeit Agricultural Research Centre, Ethiopia. Academia Journal of Agricultural Research, 4(5): 241-246.

Garner, D. L. and E. S. E. Hafez. 2008. Spermatozoa and Seminal Plasma in Reproduction In Farm Animals. Edited by E. S. E. Hafez and B. Hafez . $7^{\text {th }}$ edition. Lea and Febiger. Philadelphia: 167-188.

Getachew, T. 2016. A Review Article of Artificial Insemination in Poultry. World's Veterinary Journal. 6 (1): 2635 .

Habibullah, M., M.A. Hashem, M. S. Rana, and M. H. Islam. 2015. Effect of Artificial Insemination on different production parameter in Hubbard classic broiler parent stock. J. Bangladesh Agril. Univ. 13(1): 71-77.

Hafez, E. S. E. 2008. Artificial insemination. In E.S.E. Hafez. Ed. Reproduction in Farm Animals. $7^{\text {th }}$ edition. Lea and Febiger. Philadelpia.

Hudson, G. H., A. V. Omprakash, and K. Premavalli. 2016. Effect of Semen Diluents, Dilution Rates and Storage Periods on Live and Abnormal Spermatozoa of Pearl Guinea Fowls. Asian Journal of Animal and Veterinary Advances. 11: 411-416.

Iswati., N. Isnaini, dan T. Susilawati. 2017. Fertilitas Spermatozoa Ayam Buras dengan Penambahan Antioksidan Glutathione dalam Pengencer Ringer's Selama Simpan Dingin. Jurnal IlmuIlmu Peternakan 27 (1): 107 - 115.

Iswati., N. Isnaini, and T. Susilawati. 2018. Effect of Addition of Glutathione In Diluent Ringer's on Spermatozoa Quality of Domestic Chicken During Cold Storage. Asian Journal of Microbiology Biotechnology Environment. Sceince. 20(1): 12-20.

Lukaszewicz, E. 2001. Effects of semen filtation and dilution rate on morphology and fertility of frozen gander spermatozoa. Theiogenology.
55: 1819-1829.

Lukaszewicz, E. 2002. An effective method for freezing White Italian gander semen. Theriogenology. 58:19-27.

Madeddu, M. L. Zaniboni., M. G. Mangiagalli, C. Cassinelli, and S. Cerolini. 2013. Egg related parameters affecting fertility and hatchability in the Italian bantam breed Mericanel della Brianza. Animal Reproduction Science 137: 214-219.

Modupe, O., A. C Livinus, and N. B. Ifeany. 2013. Semen Quality Characteristic and Effect of Mating Ratio on Reproductive Performance of Hubbarrd Broiller Bredders. Journal of Agriculture Science. 5(1) 154-159.

Mohan, J., Sharma, S. K., KollurI, G., Singh, R. P., Tyagi, J. S. and Kataria, J. M. 2015. Selection od Diluent for short Term Preservation of Guinea Fowl Semen. Asian Journal of Animal and Veterinary Advances. 10(8): 360-364.

Mohan, J., Sharma, S. K., KollurI, G., Singh, R.P., Tyagi, J.S. and Kataria, J.M. 2016. Semen quality characteristics and seasonality in different varieties of male guinea fowl. Advances in Animal and Veterinary Sciences. 4 (6): 320-326.

Mohan, J., Sastry, K.V.H. and Kataria, J.M. 2017. A Process for the Preparation of CARI Poultry Semen Diluent' in patent office New Delhi. Patent filed on 28/02/2017, Application number 201711007119.

Mohan, J., K. Sharma, G. Kolluri and K. Dhama. 2018. History of Artificial Insemination in Poultry, It's Components and Significance. World's Poultry Science Journal. 74: 1-14.

Nahak, A.K., Giri, S.C., Mohanty, D.N., Mishra, P.C. and Dash, S.K. 2015. Effect of frequency of collection on seminal characteristics of White Pekin duck. Asian Pacific Journal of Reproduction. 4 (1): 70-73.

Peters SO, O.D. Shoyebo, B.M. Ilori, M.O. 
Ozoje, C.O.N. Ikeobi and O.A. Adebambo. 2008. Semen quality traits of seven strain of chickens raised in humid tropics. International Journal of Poultry Science. 7: 949-953

Ridwan dan Rusdin. 2008. Konservasi Semen Ayam Buras Menggunakan Berbagai Pengencer Terhadap Fertilitas Dan Periode Fertil Spermatozoa Pasca Inseminasi Buatan.J. Agroland.15 (1) : $63-67$.

Siudzin'ska, A and E. Łukaszewicz. 2008. Effect of Semen Extenders and Storage Time on Sperm Morphology of Four Chicken Breeds. J. Appl. Poult. Res. 17:101-108

Susilawati, T. 2011. Spermatology. UB Press. Malang.

Tabatabaei, S. 2010. The effect Spermatozoa Number on Fertility Rate of Chicken in Artificial Insemination Programs. Journal of Animal and Veterinary Advances. 9(12): 17-19.
Tarif, A.M.M., M. M.U. Bhuiyan, R. N. Ferdousy, N. S. Juyena and M. B. R. Mollah. 2013. Evaluation of semen quality among four chicken lines. IOSR Journal of Agriculture and Veterinary Science (IOSR-JAVS) 6 (5): 7-13.

Tangpakdeewijit, S., S. Ponchunchoovong and T. Vongpralub. 2015. Effect of extenders on frozen semen quality of Thai native chicken (Lueng hang kao). Khon Kaen Agr. J. 43 Suppl. 2.

Vasicek, J., L.Kuzelova, B. Kulikova, and P. Chrenek. 2015. Effect of diluent and storage time on sperm characteristics of rooster insemination doses. Avian Biology Research 8 (1): 41-26.

Yamte, K., B. Wantow, E.de Queljoe. 2013. Perbedaan motilitas Spermatozoa Sapi Jantan (Frisian holstein) setelah pemberian cairan Kristaloid Ringer Laktat. Jurnal e-Biomedik 1(1): 185189. 